\title{
Classification and surgical management of temporomandibular joint ankylosis: a review
}

\author{
Varsha Haridas Upadya ${ }^{1}$, Hari Kishore Bhat ${ }^{1,2}$, B.H. Sripathi Rao ${ }^{3}$, Srinivas Gosla Reddy ${ }^{4,5}$ \\ ${ }^{I}$ Department of Oral and Maxillofacial Surgery, Yenepoya Dental College and Hospital, Yenepoya (Deemed to be University), Mangalore, \\ ${ }^{2}$ Center for Craniofacial Anomalies, Yenepoya (Deemed to be University), Mangalore, ${ }^{3}$ Yenepoya (Deemed to be University), Mangalore, \\ ${ }^{4}$ Faculty of Dentistry, All India Institute of Medical Sciences (AIIMS) Rishikesh, Rishikesh, \\ ${ }^{5}$ GSR Institute of Craniofacial Surgery, Hyderabad, India
}

\begin{abstract}
J Korean Assoc Oral Maxillofac Surg 2021;47:239-248)
The paper reviews various classifications and surgical techniques for the treatment of temporomandibular joint ankylosis. PubMed, EBSCO, Web of Science, and Google Scholar were searched using a combination of keywords. Articles related to classification, resection-reconstruction of the temporomandibular joint, and management of airway obstruction were considered and categorized based on the objectives. Seventy-nine articles were selected, which included randomized clinical trials, non-randomized controlled cohort studies, and case series. Though several classifications exist, most classifications are centered on the radiographic extent of the ankylotic mass and do not include the clinical and functional parameters. Hence there is a need for a comprehensive staging system that takes into consideration the age of the patient, severity of the disease, clinical, functional, and radiographic findings. Staging the disease will help the clinician to adopt a holistic approach in treating these patients. Interpositional arthroplasty (IA) results in better maximal incisal opening compared with gap arthroplasty, with no significant difference in recurrent rates. Distraction osteogenesis (DO) is emerging as a popular technique for the restoration of symmetry and function as well as for relieving airway obstruction. IA, with a costochondral graft, is recommended in growing patients and may be combined with or preceded by DO in cases of severe airway obstruction. Alloplastic total joint replacement combined with fat grafts and simultaneous osteotomy procedures are gaining popularity. A custom-made total joint prosthesis using CAD/ CAM can efficiently overcome the shortcomings of stock prostheses.
\end{abstract}

Key words: Temporomandibular joint, Ankylosis, Classification, Arthroplasty, Distraction osteogenesis [paper submitted 2020. 8. 23 / revised 2020. 10. 30 / accepted 2020. 11. 2]

\section{Introduction}

Temporomandibular joint ankylosis (TMJA), arising as a result of fibrous or bony fusion of the condylar head to the glenoid fossa, is a formidable problem for the patient and a challenge to the surgeon ${ }^{1}$. This disorder is characterized by the restriction of mandibular movements resulting in difficulties in chewing, speech impairment, facial deformity, airway compromise, and psychosocial problems, especially

\section{Varsha Haridas Upadya}

Department of Oral and Maxillofacial Surgery, Yenepoya Dental College, Deralakatte, Mangalore 575018, India

TEL: +91-9740536292

E-mail: varshaupadya@yenepoya.edu.in

ORCID: https://orcid.org/0000-0002-3428-0456

(c) This is an open-access article distributed under the terms of the Creative Commons Attribution Non-Commercial License (http://creativecommons.org/ licenses/by-nc/4.0/), which permits unrestricted non-commercial use, distribution, and reproduction in any medium, provided the original work is properly cited.

Copyright (C) 2021 The Korean Association of Oral and Maxillofacial Surgeons. in younger individuals ${ }^{2}$. Trauma and infection are the leading causes; however, TMJA can also occur following TMJ surgery and systemic diseases, like rheumatoid arthritis ${ }^{3}$. The mainstay of treatment for TMJA across the world is surgery; however, the choice of technique and sequence of management vary among surgeons and institutions. The objectives of this review are:

1) To review the existing classification systems proposed for TMJA.

2) To compare the postoperative maximal incisal opening (MIO) distance between the upper and lower incisal edges during maximal opening and the recurrence rates of gap arthroplasty (GA) - the creation of a gap between the ramus and glenoid fossa following the resection of the ankylotic mass, interpositional arthroplasty (IA) - interpositioning an autogenous/alloplastic material in the gap created following GA to prevent contact between the bony surfaces, and joint reconstruction methods. 
3) To review various treatment options and sequences for the surgical management of TMJA.

4) To review the management of obstructive sleep apnea (OSA) in patients with TMJA.

\section{Methods}

PubMed, EBSCO, Web of Science, Science Direct, and Google Scholar were searched using a combination of search terms: temporomandibular joint ankylosis, TMJ ankylosis, ankylosis classification, ankylosis resection, gap arthroplasty, interpositional arthroplasty, temporalis myofascial flap, costochondral graft, total joint replacement, obstructive sleep apnea, distraction osteogenesis physiotherapy, and airway obstruction.

The search was not time-bound. Articles published in English and articles with English translations were considered. The screening of all relevant reports was performed using the title and abstract and the full texts of relevant studies were retrieved for evaluation.

The retrieved articles were segregated into 3 categories based on the objectives:

1) Articles proposing/describing the classification of TMJA

2) Articles describing the surgical management of TMJA

3) Articles on the management of airway obstruction in patients with TMJ ankylosis

\section{Inclusion criteria}

Articles pertaining to:

1) Patients with congenital/acquired TMJA

2) Randomized clinical trials, non-randomized controlled cohort studies, and case series

\section{Exclusion criteria}

1) Articles without English translations

2) Articles reporting conditions that may contribute to mouth opening restriction and airway obstruction for reasons other than TMJA

3) Animal studies

4) Case reports, technical notes, and reviews

\section{Results}

Seventy-seven articles pertaining to various aspects of TMJA were selected, which included randomized clinical trials, non-randomized controlled cohort studies, and case series.

\section{Classification}

TMJA has been broadly classified by Kazanjian ${ }^{4}$ as true ankylosis when the joint is affected and false ankylosis when the fusion is extra-articular. TMJA is also classified as fibrous, bony, or mixed types according to the type of tissue growing within the joint ${ }^{5}$. Over the years several classification systems have been proposed for TMJA ${ }^{4-11}$, which are widely based on the radiographic extent of the ankylotic mass and the histologic features. Most of the classifications are modifications of the classification proposed by Sawhney ${ }^{6}$. Most classifications are centered on the radiographic extent of the ankylotic mass and do not include the clinical and functional parameters. The overview of the classifications is listed in Table 1.

\section{Management strategies}

1) Gap arthroplasty vs interpositional arthroplasty

Four main surgical techniques are currently advocated in the treatment of TMJA: (1) GA, (2) IA, (3) reconstruction of the joint with autogenous grafts, alloplastic materials, or a combination of both, and (4) distraction osteogenesis (DO)/ orthognathic surgery for secondary deformity correction ${ }^{12}$.

GA is the oldest technique used in treating TMJA and evolved from the 19th-century practice of simply dividing the bone to separate the ramus from the skull base. Since this resulted in higher rates of recurrence, the gap between the segments was increased, giving rise to the GA technique ${ }^{13}$.

GA is technically less challenging, with a shorter operation time and less expense compared to IA; however, the rates of reankylosis are higher ${ }^{2}$. GA is also believed to require a larger gap $(10 \mathrm{~mm})$ compared to IA $(5 \mathrm{~mm})$ to prevent reankylosis, which results in increased shortening of the ramus ${ }^{2}$. Babu et al. ${ }^{14}$, found that minimal gap IA, with the total removal of the ankylotic mass from the mediolateral aspect, is an effective way of preventing recurrence.

Rajan et al. ${ }^{15}$, described transoral access for GA for smallto moderate-size ankylotic masses. They reported that, though transoral access is technically challenging, it does not produce facial scars and facial nerve injury.

Ten studies ${ }^{16-25}$ comparing GA and IA for the treatment of TMJA, were evaluated. Eight of the nine studies concluded that IA results in better MIO and decreased incidence of re- 
Table 1. Classification of TMJ ankylosis

\begin{tabular}{|c|c|c|c|c|}
\hline No. & Study & Sample size & Parameter & Description of each type \\
\hline 1 & Topazian $^{5}$ (1966) & 44 & & $\begin{array}{l}\text { Stage I: ankylotic bone limited to the condylar process } \\
\text { Stage II: ankylotic bone extending to the sigmoid notch } \\
\text { Stage III. ankylotic bone extending to the coronoid process }\end{array}$ \\
\hline 2 & Sawhney $^{6}(1986)$ & 70 & $\begin{array}{l}\text { Extent of fusion } \\
\text { visualized on } \\
\text { tomograms }\end{array}$ & $\begin{array}{l}\text { Type I: significantly deformed but visible condylar head. TMJ } \\
\text { movement is not possible due to fibroadhesions. } \\
\text { Type II: consolidation of the deformed condylar head and } \\
\text { articular surface mainly at the edges and in the anterior and } \\
\text { posterior parts of the structures. The medial part of the condylar } \\
\text { head remains undamaged. } \\
\text { Type III: involvement of the mandibular ramus and zygomatic } \\
\text { arch. Medially, an atrophic and displaced fragment of the } \\
\text { anterior part of the condylar head is present. } \\
\text { Type IV: complete obliteration of the joint by a bony ankylotic } \\
\text { mass between the cranial base and the mandibular ramus. }\end{array}$ \\
\hline 3 & Durr et al. ${ }^{7}$ (1993) & $\begin{array}{l}10 \text { patients } \\
\text { (15 joints })\end{array}$ & $\begin{array}{l}\text { Heterotopic bone } \\
\text { formation within } \\
\text { the ankylotic mass }\end{array}$ & $\begin{array}{l}\text { So bone islands visible (Grade 0) } \\
\text { Periarticular bone formation (Grade } 2 \text { ) } \\
\text { Apparent bony ankylosis (Grade } 3 \text { ) } \\
\text { All } 3 \text { grades are further classified as symptomatic (S) and } \\
\text { asymptomatic (A). Symptomatic: severe pain, reduced inter- } \\
\text { incisal opening (15 mm or less), closed locking of the jaw, or } \\
\text { decreased lateral or protrusive movement. }\end{array}$ \\
\hline 4 & $\begin{array}{l}\text { El-Hakim and } \\
\text { Metwalli }^{8}(2002)\end{array}$ & $\begin{array}{l}33 \text { patients } \\
\text { (42 joints) }\end{array}$ & $\begin{array}{l}\text { Relation of the } \\
\text { ankylosed mass to } \\
\text { the surrounding } \\
\text { vital structures, } \\
\text { especially at the } \\
\text { base of the skull } \\
\text { as seen on post- } \\
\text { contrast axial and } \\
\text { coronal CT }\end{array}$ & $\begin{array}{l}\text { Class I: unilateral and bilateral fibrous ankylosis. The condyle } \\
\text { and glenoid fossa retain their original shape, and the maxillary } \\
\text { artery is in normal anatomical relation to the ankylosed mass. } \\
\text { Class II: unilateral or bilateral bony fusion between the condyle } \\
\text { and the temporal bone. The maxillary artery lies in normal } \\
\text { anatomical relation to the ankylosed mass. } \\
\text { Class III: the distance between the maxillary artery and the } \\
\text { medial pole of the mandibular condyle is less on the ankylosed } \\
\text { than on the normal side or the maxillary artery runs within the } \\
\text { ankylotic bony mass. } \\
\text { Class IV: extensive bone formation and fusion to the skull base } \\
\text { with a close relationship to vital structures such as the pterygoid } \\
\text { plates, the carotid and jugular foramina and foramen spinosum. }\end{array}$ \\
\hline 5 & He et al. ${ }^{9}(2011)$ & $\begin{array}{l}84 \text { patients } \\
\text { (124 joints })\end{array}$ & $\begin{array}{l}\text { Bony/fibrous fusion } \\
\text { as seen on coronal } \\
\text { CT scan images }\end{array}$ & $\begin{array}{l}\text { Type A1: fibrous ankylosis without bony fusion of the joint } \\
\text { Type A2: bony fusion on the lateral aspect of the joint, while the } \\
\text { residual condyle fragment is bigger than } 0.5 \text { of the condylar } \\
\text { head in the medial side. } \\
\text { Type A3: similar to A } 2 \text { but the residual condylar fragment is } \\
\text { smaller than } 0.5 \text { of the condylar head } \\
\text { Type A4: ankylosis with complete bony fusion of the joint. }\end{array}$ \\
\hline 6 & $\begin{array}{l}\text { Braimah et al. } \\
\text { (2018) }\end{array}$ & 36 & $\begin{array}{l}\text { Sawhney's } \\
\text { classification- } \\
\text { maxillary } \\
\text { involvement on CT } \\
\text { images }\end{array}$ & $\begin{array}{l}\text { fusion of the condyle, sigmoid notch and coronoid process to } \\
\text { the zygomatic arch, glenoid fossa and maxilla) }\end{array}$ \\
\hline 7 & Xia et al. ${ }^{11}$ (2019) & $\begin{array}{l}71 \text { patients } \\
\text { (102 ankylosed } \\
\text { joints) }\end{array}$ & $\begin{array}{l}\text { CT images } \\
\text { Post trauma period } \\
\text { Maximal mouth } \\
\text { opening } \\
\text { Complication rate } \\
\text { Histopathological } \\
\text { changes }\end{array}$ & $\begin{array}{l}\text { Type I: non-bony ankylosis with near normal joint space; } \\
\text { Type II: lateral bony ankylosis with a radiolucent line within a } \\
\text { normal joint space; } \\
\text { Type III: complete bony ankylosis with only a radiolucent line; } \\
\text { and } \\
\text { Type IV: extensive bony ankylosis with absence of radiolucent } \\
\text { line }\end{array}$ \\
\hline
\end{tabular}

(TMJ: temporomandibular joint, CT: computed tomography)

Varsha Haridas Upadya et al: Classification and surgical management of temporomandibular joint ankylosis: a review. J Korean Assoc Oral Maxillofac Surg 2021

currence compared to GA indicating that the interpositional material acted as a barrier, preventing recurrence.(Table 2)

A variety of autogenous, alloplastic, and xenografts have been used as interpositional grafts ${ }^{12}$. Temporalis muscle flap ${ }^{26}$, temporalis fascia ${ }^{14}$, and temporalis muscle and fascia flap ${ }^{12,27}$ are popularly used and preferred by most surgeons due to their proximity to the surgical site and bulk that they provide. Chossegros et al. ${ }^{28}$ compared the different interpositional 
Table 2. Comparison of gap arthroplasty and interpositional arthroplasty

\begin{tabular}{|c|c|c|c|c|c|}
\hline Study & $\begin{array}{l}\text { Sample size } \\
\text { (GA/IA) }\end{array}$ & $\begin{array}{l}\text { Mean age of } \\
\text { patients (yr) }\end{array}$ & $\begin{array}{l}\text { Follow-up } \\
\text { period (mo) }\end{array}$ & $\begin{array}{l}\text { Increase in MIO } \\
(\mathrm{mm}), \mathrm{GA} / \mathrm{IA}\end{array}$ & $\begin{array}{c}\text { Incidence of } \\
\text { reankylosis, \% (GA/IA) }\end{array}$ \\
\hline Tanrikulu et al. ${ }^{16}(2005)$ & $8 / 9$ & 12 & $12-180$ & $28.5 / 29.2$ & $0(0 / 8) / 11.1(1 / 9)$ \\
\hline Ramezanian and Yavary ${ }^{17}(2006)$ & $22 / 26$ & 19.5 & 59 & $24.33 / 23.6$ & $45.4(10 / 22) / 23.1(6 / 26)$ \\
\hline Zhi et al. ${ }^{18}(2009)$ & $24 / 17$ & 22.25 & $12-132$ & $18.58 / 20.57$ & $12.5(3 / 24) / 0(0 / 17)$ \\
\hline Danda et al. ${ }^{19}$ (2009) & $8 / 8$ & 9.6 & 26.5 & $27.37 / 27.93$ & $12.5(1 / 8) / 12.5(1 / 8)$ \\
\hline Elgazzar et al. ${ }^{20}(2010)$ & $11 / 14$ & 19.43 & $14-96$ & 29.1/30.7 & $18.2(2 / 11) / 7.1(1 / 14)$ \\
\hline Mansoor et al. ${ }^{21}$ (2013) & $30 / 30$ & 13.3 & 6 & $24.33 / 23.77$ & $0(0 / 30) / 3.3(1 / 30)$ \\
\hline Holmlund et al. ${ }^{22}$ (2013) & $14 / 22$ & 49 & $12-108$ & $30.9 / 36.7$ & $0(0 / 14) / 0(0 / 22)$ \\
\hline Shaikh et al. ${ }^{23}$ (2013) & $10 / 10$ & 15.15 & 12 & $29.4 / 32.9$ & $0(0 / 10) / 0(0 / 10)$ \\
\hline Bhatt et al. ${ }^{24}(2014)$ & $207 / 55$ & 12.95 (GA) & 43 & $29.76 / 30.51$ & $14.6(26 / 178) / 4.8(2 / 42)$ \\
\hline Bansal et al. ${ }^{25}$ (2014) & $30 / 30$ & $\begin{array}{l}13.3 \text { (IA) } \\
26.7\end{array}$ & 24 & $12.6 / 19$ & $26.6(8 / 30) / 0(0 / 30)$ \\
\hline
\end{tabular}

(GA: gap arthroplasty, IA: interpositional arthroplasty, MIO: maximal incisal opening)

Varsha Haridas Upadya et al: Classification and surgical management of temporomandibular joint ankylosis: a review. J Korean Assoc Oral Maxillofac Surg 2021

materials (skin, temporal muscle, homologous cartilage) used over a period of 22 years. Good results were obtained in over $92 \%$ of the cases with a full-thickness skin graft and $83 \%$ of cases with a temporal muscle flap. Homologous cartilage yielded poor results ${ }^{28}$.

Following GA, Dimitroulis ${ }^{13}$ filled the resultant gap with an autogenous dermis fat graft procured from the patient's groin. Though favorable results were obtained, the authors could not draw conclusions due to the small sample size. Full-thickness skin-subcutaneous fat grafts have been used successfully ${ }^{29}$. Malhotra et al. ${ }^{30}$ described a simple and cost-effective procedure of lateral arthroplasty followed by interpositioning with a buccal fat pad for Sawhney type III ankylosis. Studies on the various interpositional materials used $\mathrm{d}^{12-14,26-29,31}$ are listed in Table 3.

In cases of reankylosis following GA, IA has been recommended as the treatment of choice. Following interpositioning with various materials, if the ramal height is not adequately restored, then reconstructing the joint with autogenous/alloplastic materials should be considered ${ }^{2}$.

\section{2) Reconstruction of the joint and total joint replacement}

Reconstruction of the ramal-condylar unit with a costochondral graft (CCG) has been advocated, especially in young patients, as the graft is believed to possess growth potential $^{1}$. Sharma et al. ${ }^{32}$ observed that children with a CCG showed improved mandibular symmetry and growth with adequate mouth opening. However, studies have shown that, compared to CCG reconstruction, IA results in greater improvement in $\mathrm{MIO}$ with recurrence rates that are comparable ${ }^{16,33-35}$. The CCG appears to produce greater MIO when compared to alloplastic joint reconstruction (AJR); however, in terms of pain reduction, AJR seems to be superior to $\mathrm{CCG}^{1,36,37}$.
Since DO obviates the need for a donor site, it is gaining popularity in the management of TMJA. DO is indicated as a primary mandibular lengthening procedure or a secondary procedure when other procedures have failed or produced inadequate results ${ }^{20}$.

Chen et al. ${ }^{38}$ divided 130 ankylosis patients into 3 groups based on age. They found that children showed a significantly greater rate of reankylosis compared with adults. In the adults, reconstruction was done using a coronoid process graft (CPG), DO, or prosthesis implantation for type III. The CPG resulted in the highest recurrence rate compared to the other two treatment modalities.

Sahoo et al. ${ }^{39}$ compared the outcomes of 3 groups of TMJA patients: IA with temporalis myofascial flap (TMMF), $\mathrm{IA}+\mathrm{TMMF}+\mathrm{CCG}$ reconstruction, and $\mathrm{IA}+\mathrm{TMMF}+\mathrm{DO}$. No statistical difference was seen between the groups in terms of the MIO. IA with TMMF is recommended in patients where growth is completed. In younger patients, the CCG allowed for growth and maintenance of ramal height. DO for joint reconstruction can be performed at any age.

The commonly used TMJR (TMJ reconstruction) systems are TMJ Concepts, Biomet, and Nexus. Wolford et al. ${ }^{40}$, compared Concepts and Nexus prostheses in patients with TMJA and reported that 25 of $76(33 \%)$ Nexus prostheses had to be removed due to elevated pain scores attributed to device failure. Biomet and TMJ Concepts have shown comparable results; however, TMJ Concepts has the advantage of being backed by a longer follow-up compared to Biomet ${ }^{41}$.

Custom-made patient-fitted CAD/CAM prostheses, fabricated on stereolithographic models, are gaining popularity over stock prostheses as the custom TMJR components interface well with the host anatomy. The majority of the issues with the stock components, resulting from fit-miscalculation, are not present ${ }^{42,43}$. 
Table 3. Autogenous grafts and alloplastic materials used in interpositional arthroplasty

\begin{tabular}{|c|c|c|c|c|c|c|c|}
\hline Study & $\begin{array}{l}\text { Sample } \\
\text { size }\end{array}$ & Age (yr) & $\begin{array}{l}\text { Interpositional } \\
\text { material }\end{array}$ & $\begin{array}{c}\text { Mean } \\
\text { follow-up } \\
\text { period (mo) }\end{array}$ & $\begin{array}{c}\text { Mean } \\
\text { preoperative } \\
\text { MIO }(\mathrm{mm})\end{array}$ & $\begin{array}{c}\text { Mean } \\
\text { postoperative } \\
\text { MIO }(\mathrm{mm})\end{array}$ & $\begin{array}{l}\text { Author's } \\
\text { conclusion }\end{array}$ \\
\hline Chossegros et al. ${ }^{28}$ & 13 & 19 & Full thickness skin graft & 36 & 15.6 & 37.1 & Full-thickness skin graft \\
\hline (1997) & 6 & 46 & Temporalis muscle flap & 36 & 16.8 & 31.1 & $\begin{array}{l}\text { and pedunculated } \\
\text { temporalis muscle } \\
\text { flap are the best } \\
\text { interpositional } \\
\text { materials in adults. }\end{array}$ \\
\hline $\operatorname{Kim}^{12}(2001)$ & 7 & 31.1 & $\begin{array}{l}\text { Temporalis muscle and } \\
\text { fascia flap }\end{array}$ & 20.1 & 15 & 36.1 & $\begin{array}{l}\text { Temporalis muscle and } \\
\text { fascia flap is effective } \\
\text { in treating TMJ } \\
\text { ankylosis. }\end{array}$ \\
\hline Dimitroulis $^{13}$ (2004) & 11 & 32.5 & Dermis fat graft (groin) & 41.5 & 15.6 & 35.7 & $\begin{array}{l}\text { Autogenous dermis-fat } \\
\text { interpositional graft is } \\
\text { effective in preventing } \\
\text { re-ankylosis up to } 6 \\
\text { years following surgical } \\
\text { release. }\end{array}$ \\
\hline Bayat et al. ${ }^{26}$ (2009) & 34 & 21.5 & Temporalis muscle flap & 21.3 & 4.9 & 32.8 & $\begin{array}{l}\text { Satisfactory mouth } \\
\text { opening achieved } \\
\text { with only } 2 \text { cases of } \\
\text { recurrence }\end{array}$ \\
\hline $\begin{array}{l}\text { Guruprasad et al. }{ }^{27} \\
\text { (2010) }\end{array}$ & 9 & 24.7 & $\begin{array}{l}\text { Temporalis muscle and } \\
\text { fascia flap }\end{array}$ & 18.3 & 11.7 & 38.3 & $\begin{array}{l}100 \% \text { success rate with } \\
\text { increased mandibular } \\
\text { mobility and improved } \\
\text { function }\end{array}$ \\
\hline $\begin{array}{l}\text { Thangavelu et al. } \\
\text { (2011) }\end{array}$ & 7 & 27.2 & $\begin{array}{l}\text { Full thickness skin- } \\
\text { subcutaneous fat grafts } \\
\text { from abdomen }\end{array}$ & 23.2 & 3.4 & 31.7 & $\begin{array}{l}\text { Donor site provides } \\
\text { ample tissue to fill } \\
\text { the dead space. The } \\
\text { skin prevents fat } \\
\text { fragmentation. }\end{array}$ \\
\hline Babu et al. ${ }^{14}$ (2013) & 15 & 20 & Temporalis fascia & 36 & 3.8 & 29.4 & $\begin{array}{l}\text { Maximum MIO between } \\
\text { 30-40mm was achieved } \\
\text { with no recurrence at } \\
\text { the end of } 3 \text { years. }\end{array}$ \\
\hline $\begin{array}{l}\text { Shakeel et al. }{ }^{31} \\
\text { (2016) }\end{array}$ & $\begin{array}{l}38 \\
12 \\
25\end{array}$ & $\begin{array}{l}12.4 \\
13.6 \\
14.3\end{array}$ & $\begin{array}{l}\text { Costochondral graft } \\
\text { Acrylic spacer } \\
\text { Temporalis myofascial } \\
\text { flap }\end{array}$ & 12 & $\begin{array}{r}10.5 \\
15.3 \\
7.1\end{array}$ & $\begin{array}{l}34.3 \\
28.7 \\
38.4\end{array}$ & $\begin{array}{l}\text { The spacer group showed } \\
\text { the least improvement } \\
\text { in MIO and maximum } \\
\text { recurrence. The } \\
\text { temporalis myofascial } \\
\text { flap showed maximum } \\
\text { improvement in MIO } \\
\text { and no recurrence. }\end{array}$ \\
\hline
\end{tabular}

(MIO: maximal incisal opening, TMJ: temporomandibular joint)

Varsha Haridas Upadya et al: Classification and surgical management of temporomandibular joint ankylosis: a review. J Korean Assoc Oral Maxillofac Surg 2021

The placement of autologous fat grafts around the total joint replacement (TJR) to obliterate the dead space around the prosthesis has shown promising results and is gaining popularity. Significant work on fat grafts by Wolford et al. $^{40,44,45}$ demonstrate a significant advancement in preventing the recurrence of ankylosis. The fat grafts prevent the organization of a clot, extensive fibrosis, and heterotopic calcification. The outcomes of various studies ${ }^{41,44-49}$ on the use of autologous fat grafts, along with a TMJ prosthesis, are shown in Table 4.
3) Role of postoperative physiotherapy

Relapse can be prevented by early and rigorous physiotherapy ${ }^{15}$ for a minimum of 6 months ${ }^{50}$. Several techniques and appliances have been used for the maintenance of postoperative mouth opening and physiotherapy, such as stacked tongue depressors, interocclusal splints ${ }^{51}$, TheraBite, custommade devices (including screws or cones with enlarging diameters), wedge exercisers, elastic traction, and hydraulic passive motion devices ${ }^{52}$. Shirani et al. ${ }^{53}$, found better results in the IA group that used postoperative activator appliances for physiotherapy compared with the group that underwent $\mathrm{CCG}$ reconstruction. 
Table 4. Studies on autogenous fat grafting and alloplastic total joint replacement

\begin{tabular}{|c|c|c|c|c|c|c|c|}
\hline Study & $\begin{array}{l}\text { Sample } \\
\text { size }\end{array}$ & $\begin{array}{l}\text { Mean age of } \\
\text { patients (yr) }\end{array}$ & $\begin{array}{l}\text { Prosthesis } \\
\text { used }\end{array}$ & $\begin{array}{c}\text { Source of } \\
\text { autologous fat }\end{array}$ & $\begin{array}{l}\text { Follow-up } \\
\text { period (mo) }\end{array}$ & $\begin{array}{l}\text { Increase in } \\
\text { MIO (mm) }\end{array}$ & $\begin{array}{l}\text { Incidence of } \\
\text { reankylosis }\end{array}$ \\
\hline Wolford and Karras ${ }^{44}$ (1997) & 15 (22 joints) & 40.1 & $\begin{array}{l}\text { Techmedica } \\
\text { custom made } \\
\text { total joint } \\
\text { prosthesis }\end{array}$ & Abdominal fat & 21.8 & 11.8 & None \\
\hline \multirow[t]{2}{*}{ Wolford et al. ${ }^{40}$ (2008) } & $\begin{array}{l}115(203 \\
\text { joints })\end{array}$ & NA & $\begin{array}{l}\text { Group 1: } \\
\text { Christensen total } \\
\text { joint prostheses }\end{array}$ & Abdominal fat & 12 & 3.5 & None \\
\hline & & & $\begin{array}{l}\text { Group 2: TMJ } \\
\text { Concepts total } \\
\text { joint prostheses }\end{array}$ & & & 6.8 & \\
\hline Mercuri et al. ${ }^{46}(2008)$ & 20 (33 joints) & $44 \pm 11.3$ & $\begin{array}{l}\text { TMJ Concepts } \\
\text { Patient-Fitted } \\
\text { Total TMJ } \\
\text { Prosthesis } \\
\text { System }\end{array}$ & Abdominal fat & $50.4 \pm 28.8$ & 21.15 & None \\
\hline ShanYong et al. ${ }^{47}$ (2015) & 15 (19 joints) & 55.8 & $\begin{array}{l}\text { Biomet-Lorenz } \\
\text { stock } \\
\text { Prosthesis }\end{array}$ & $\begin{array}{l}\text { Retro-mandibular } \\
\text { subcutaneous fat }\end{array}$ & $18-72$ & NA & $\begin{array}{l}2 \text { cases of } \\
\text { heterotopic } \\
\text { bone } \\
\text { formation } \\
\text { in which fat } \\
\text { grafts were } \\
\text { not placed. }\end{array}$ \\
\hline Wolford et al..$^{45}(2016)$ & 32 (48 joints) & 39 & TMJ Concepts & $\begin{array}{l}\text { Abdominal and } \\
\text { other sites }\end{array}$ & 59.5 & 20.5 & $\begin{array}{l}2 \text { cases of } \\
\text { heterotopic } \\
\text { bone }\end{array}$ \\
\hline $\begin{array}{l}\text { Selbong et al. }{ }^{48} \text { (2016) } \\
\text { Roychoudhury et al. }^{49} \text { (2017) }\end{array}$ & 11 (17 joints) & $\begin{array}{c}55.3 \\
18.82 \pm 2.7\end{array}$ & $\begin{array}{l}\text { TMJ Concepts } \\
\text { Stock Total TMJ } \\
\text { Replacement }\end{array}$ & $\begin{array}{l}\text { Abdominal fat } \\
\text { Buccal pad fat }\end{array}$ & $\begin{array}{l}15.3 \\
12-30\end{array}$ & $\begin{array}{c}16 \\
38 \pm 6\end{array}$ & $\begin{array}{l}\text { None } \\
\text { None }\end{array}$ \\
\hline
\end{tabular}

(MIO: maximal incisal opening, NA: information not available, TMJ: temporomandibular joint)

Varsha Haridas Upadya et al: Classification and surgical management of temporomandibular joint ankylosis: a review. J Korean Assoc Oral Maxillofac Surg 2021

\section{4) Correction of secondary deformities}

Simultaneous arthroplasty and DO in treatment of children with TMJA and secondary mandibular deformities was performed by Ma et al. ${ }^{54}$. Following ankylosis release, DO was used to lengthen the mandibular body, ramus, or both. They found that it was an effective technique; however, the longterm influence on mandibular growth needs to be further investigated.

Zhang et al. ${ }^{55}$ performed DO, initially followed by arthroplasty or TMJ reconstruction $(n=40)$. All patients showed improvement in $\mathrm{MIO}$ and appearance with the disappearance of snoring. Airway space significantly increased. The authors suggest that undertaking DO as the initial surgery and arthroplasty/joint reconstruction, in the second stage, may produce desirable results, especially for patients with obstructive sleep apnea-hypopnea syndrome (OSAHS). However, some patients may require orthognathic surgery during or after the second stage, to improve occlusion and face shape.

Simultaneous maxillo-mandibular DO followed by IA was performed by Mehrotra et al. ${ }^{56}$ in patients with unilateral TMJA $(n=10)$ with an aesthetic deformity and maxillary cant. Ankylosis release and IA with temporal fascia was performed as a second surgery, along with genioplasty when required. All cases showed marked improvement in facial symmetry occlusal cant and mandibular retrusion. The authors concluded that DO followed by IA improves facial esthetics, along with function.

Anchlia et al. ${ }^{57}$ proposed a single-stage management plan for TMJA in adult patients with an apnea-hypopnea index (AHI) score of less than 20. Ankylosis is released and TMMF, abdominal dermis fat or buccal fat pad is interposed in the gap. The ramus-condyle unit (RCU) is reconstructed by vertical ramus osteotomy or L osteotomy and extended advancement centering genioplasty is performed.

Neocondyle distraction with internal distractors has been used by Sharma et al. ${ }^{58}$ for the reconstruction of the RCU in five patients following GA. They advocate this approach for restoring physiological TMJ function, simultaneously correcting hard and soft tissue deficiency and preventing reankylosis.

Gabbay et al. ${ }^{59}$ compared transport DO and Matthews device arthroplasty. Group I underwent mandibular advancement by DO, followed by condylar resection, the lining of the glenoid fossa and transport distraction. In Group II the 
Matthews devices were anchored to the temporal bone and mandibular rami. Although both techniques were successful, long-term relapse was avoided with a Matthews device.

\section{5) Airway management}

The effectiveness of maxillo-mandibular advancement (MMA) by orthognathic surgery has been proven for patients who cannot adhere to continuous positive airway pressure (CPAP) therapy ${ }^{60,61}$ and in children in whom traditional orthognathic surgery was deemed impossible. Mandibular DO has been shown to improve the laryngeal view, as assessed by the Cormack-Lehane score, and reduce $\mathrm{AHI}^{62}$.

For children with congenital micrognathia or midface hypoplasia, DO can produce large advancements, eliminating the need for bone grafting, with less risk of relapse ${ }^{63,64}$. For later onset OSAHS, DO may be a good alternative when acute bone movement is difficult due to scarring from previous surgeries or when the risk for inferior alveolar nerve damage is high ${ }^{61}$. Primary mandibular DO for the relief of upper airway obstruction has been found to be successful in preventing tracheostomy in patients with a micrognathia/ Pierre Robin sequence and should be considered an acceptable alternative to tracheostomy ${ }^{65-67}$. Mandibular DO for airway obstruction shows excellent results in patients below 6 years who are unresponsive to conservative measures and it allows for early decannulation in patients with a previous history of tracheotomy ${ }^{68,69}$.

The simultaneous genial distraction of the non-occlusion bearing segment of the mandible along with IA has been performed in adults with stable occlusion. This not only corrects the secondary deformity and OSAHS but also does not interfere with the immediate postoperative outcome ${ }^{70}$. Li et al. $^{71}$ applied DO in adult patients for skeletal advancement and treatment of OSAHS. The application of pre-operative simulation surgery using a three-dimensional (3D) craniomaxillofacial model for precision in surgical planning ${ }^{72}$ and the use of a new generation of a curvilinear distractor for vector control and the prevention of open bite development have been advocated ${ }^{73}$.

Jia et al. ${ }^{74}$ reported a one-stage technique for the treatment of TMJA, secondary micrognathia, and a prominent mandibular angle. Resection of the ankylotic mass is performed followed by reconstruction of the ramal unit with a coronoid graft. Through a retromandibular incision, the bone posterior to the antegonial notch is resected and used to fill the gap created following mandibular advancement by inverted L-osteotomy. Advancement genioplasty is performed if required.
Srivastava et al. ${ }^{75}$ performed GA and simultaneous dual distraction as a single-stage approach for the correction of TMJA and facial asymmetry in 7 patients above the age of 12 years. The authors concluded that dual distraction is a promising technique and it overcomes the disadvantage of a single distractor where the proximal condylar segment remains unstable.

Despite the advantages of DO over conservative methods, tracheostomy, and conservative orthognathic surgery, drawbacks, such as the need for increased patient compliance, second surgery for distractor removal, and frequent hospital visits should be considered as it may produce unfavorable outcomes in non-compliant patients ${ }^{76,77}$.

Gonçalves et al. ${ }^{78}$ reported a significant immediate increase in 3D airway space following maxillomandibular counterclockwise rotation and mandibular advancement with total joint prostheses (TMJ Concepts) and fat grafting. Similar results were also reported by Coleta et al. ${ }^{79}$, who noted an immediate increase in the dimensions of the oropharyngeal airway following MMA with counter-clockwise rotation and reconstruction of the TMJ with total joint prostheses combined with fat grafting.

\section{Conclusion}

TMJA is a debilitating disease associated with adverse aesthetic, functional, and psychological sequelae. Though several classifications exist, there is a need for a comprehensive staging system that takes into consideration the age of the patient, severity of the disease, clinical, functional, and radiographic findings. Staging the disease will help the clinician in adopting a holistic approach to treat these patients.

IA results in better MIO compared to GA with no significant difference in recurrent rates. DO is emerging as a popular technique for the restoration of symmetry and function, as well as for relieving airway obstruction. IA with CCG is recommended in growing patients and may be combined with, or may be preceded by, DO in cases of severe airway obstruction. Alloplastic TJR combined with fat grafts and simultaneous osteotomy procedures are gaining popularity. A custom-made total joint prosthesis using CAD/CAM can efficiently overcome the shortcomings of a stock prosthesis.

\section{ORCID}

Varsha Haridas Upadya, https://orcid.org/0000-0002-34280456 
Hari Kishore Bhat, https://orcid.org/0000-0002-5629-0153

B.H. Sripathi Rao, https://orcid.org/0000-0003-1426-443X

Srinivas Gosla Reddy, https://orcid.org/0000-0001-9720-5501

\section{Authors' Contributions}

V.H.U. participated in data collection and wrote the manuscript. H.K.B., B.H.S.R., and S.G.R. participated in the study design. H.K.B. helped to draft the manuscript. All authors read and approved the final manuscript.

\section{Conflict of Interest}

No potential conflict of interest relevant to this article was reported.

\section{References}

1. Saeed NR, McLeod NM, Hensher R. Temporomandibular joint replacement in rheumatoid-induced disease. Br J Oral Maxillofac Surg 2001;39:71-5. https://doi.org/10.1054/bjom.2000.0565

2. Ma J, Liang L, Jiang H, Gu B. Gap arthroplasty versus interpositional arthroplasty for temporomandibular joint ankylosis: a metaanalysis. PLoS One 2015;10:e0127652. https://doi.org/10.1371/ journal.pone.0127652

3. Roychoudhury A, Parkash H, Trikha A. Functional restoration by gap arthroplasty in temporomandibular joint ankylosis: a report of 50 cases. Oral Surg Oral Med Oral Pathol Oral Radiol Endod 1999;87:166-9. https://doi.org/10.1016/s1079-2104(99)70267-2

4. Kazanjian VH. Ankylosis of the temporomandibular joint. Am J Orthod Oral Surg 1938;24:1181-206. https://doi.org/10.1016/ S0096-6347(38)90337-0

5. Topazian RG. Comparison of gap and interposition arthroplasty in the treatment of temporomandibular joint ankylosis. J Oral Surg 1966;24:405-9.

6. Sawhney CP. Bony ankylosis of the temporomandibular joint: follow-up of 70 patients treated with arthroplasty and acrylic spacer interposition. Plast Reconstr Surg 1986;77:29-40.

7. Durr ED, Turlington EG, Foote RL. Radiation treatment of heterotopic bone formation in the temporomandibular joint articulation. Int J Radiat Oncol Biol Phys 1993;27:863-9.

8. El-Hakim IE, Metwalli SA. Imaging of temporomandibular joint ankylosis. A new radiographic classification. Dentomaxillofac Radiol 2002;31:19-23. https://doi.org/10.1038/sj/dmfr/4600660

9. He D, Yang C, Chen M, Zhang X, Qiu Y, Yang X, et al. Traumatic temporomandibular joint ankylosis: our classification and treatment experience. J Oral Maxillofac Surg 2011;69:1600-7. https:// doi.org/10.1016/j.joms.2010.07.070

10. Braimah RO, Taiwo AO, Ibikunle AA, Oladejo T, Adeyemi M, Adejobi AF, et al. Temporomandibular joint ankylosis with maxillary extension: proposal for modification of Sawhney's classification. Craniomaxillofac Trauma Reconstr Open 2018;2:e15-21. https:// doi.org/10.1055/s-0038-1666852

11. Xia L, An J, He Y, Xiao E, Chen S, Yan Y, et al. Association between the clinical features of and types of temporomandibular joint ankylosis based on a modified classification system. Sci Rep 2019;9:10493. https://doi.org/10.1038/s41598-019-46519-8

12. Kim SG. Treatment of temporomandibular joint ankylosis with temporalis muscle and fascia flap. Int J Oral Maxillofac Surg
2001;30:189-93. https://doi.org/10.1054/ijom.2001.0047

13. Dimitroulis G. The interpositional dermis-fat graft in the management of temporomandibular joint ankylosis. Int J Oral Maxillofac Surg 2004;33:755-60. https://doi.org/10.1016/j.ijom.2004.01.012

14. Babu L, Jain MK, Ramesh C, Vinayaka N. Is aggressive gap arthroplasty essential in the management of temporomandibular joint ankylosis?-a prospective clinical study of 15 cases. $\mathrm{Br}$ J Oral Maxillofac Surg 2013;51:473-8. https://doi.org/10.1016/ j.bjoms.2012.11.004

15. Rajan R, Reddy NV, Potturi A, Jhawar D, Muralidhar PV, Reddy B. Gap arthroplasty of temporomandibular joint ankylosis by transoral access: a case series. Int J Oral Maxillofac Surg 2014;43:1468-72. https://doi.org/10.1016/j.ijom.2014.08.010

16. Tanrikulu R, Erol B, Görgün B, Söker M. The contribution to success of various methods of treatment of temporomandibular joint ankylosis (a statistical study containing 24 cases). Turk J Pediatr 2005;47:261-5.

17. Ramezanian M, Yavary T. Comparion of gap arthroplasty and interpositional gap arthroplasty on the temporomandibular joint ankylosis. Acta Med Iran 2006;44:391-4.

18. Zhi K, Ren W, Zhou H, Gao L, Zhao L, Hou C, et al. Management of temporomandibular joint ankylosis: 11 years' clinical experience. Oral Surg Oral Med Oral Pathol Oral Radiol Endod 2009;108:68792. https://doi.org/10.1016/j.tripleo.2009.06.041

19. Danda AK, S R, Chinnaswami R. Comparison of gap arthroplasty with and without a temporalis muscle flap for the treatment of ankylosis. J Oral Maxillofac Surg 2009;67:1425-31. https://doi. org/10.1016/j.joms.2008.12.049

20. Elgazzar RF, Abdelhady AI, Saad KA, Elshaal MA, Hussain MM, Abdelal SE, et al. Treatment modalities of TMJ ankylosis: experience in Delta Nile, Egypt. Int J Oral Maxillofac Surg 2010;39:33342. https://doi.org/10.1016/j.ijom.2010.01.005

21. Mansoor N, Khan M, Mehboob B, Din Q. Gap vs interpositional arthroplasty in the management of temporomandibular joint ankylosis. Pak Oral Dent J 2013;33:8-12.

22. Holmlund A, Lund B, Weiner CK. Mandibular condylectomy with osteoarthrectomy with and without transfer of the temporalis muscle. Br J Oral Maxillofac Surg 2013;51:206-10. https://doi. org/10.1016/j.bjoms.2012.05.011

23. Shaikh SK, Mishra M, Tiwari AK, Chander M, Gaur A, Singh H. Comparative evaluation of gap arthroplasty and interpositional arthroplasty using temporalis fascia in the management of temporomandibular joint ankylosis. J Orofac Res 2013;3:170-4.

24. Bhatt K, Roychoudhury A, Bhutia O, Pandey RM. Functional outcomes of gap and interposition arthroplasty in the treatment of temporomandibular joint ankylosis. J Oral Maxillofac Surg 2014;72:2434-9. https://doi.org/10.1016/j.joms.2014.08.012

25. Bansal V, Singh S, Garg N, Dubey P. Transport distraction osteogenesis as a method of reconstruction of the temporomandibular joint following gap arthroplasty for post-traumatic ankylosis in children: a clinical and radiological prospective assessment of outcome. Int J Oral Maxillofac Surg 2014;43:227-36. https://doi. org/10.1016/j.ijom.2013.07.745

26. Bayat M, Badri A, Moharamnejad N. Treatment of temporomandibular joint ankylosis: gap and interpositional arthroplasty with temporalis muscle flap. Oral Maxillofac Surg 2009;13:207-12. https://doi.org/10.1007/s10006-009-0174-4

27. Guruprasad Y, Chauhan DS, Cariappa KM. A retrospective study of temporalis muscle and fascia flap in treatment of TMJ ankylosis. J Maxillofac Oral Surg 2010;9:363-8. https://doi.org/10.1007/ s12663-010-0139-z

28. Chossegros C, Guyot L, Cheynet F, Blanc JL, Gola R, Bourezak $\mathrm{Z}$, et al. Comparison of different materials for interposition arthroplasty in treatment of temporomandibular joint ankylosis surgery: long-term follow-up in 25 cases. Br J Oral Maxillofac Surg 1997;35:157-60. https://doi.org/10.1016/s0266-4356(97)90554-4

29. Thangavelu A, Santhosh Kumar K, Vaidhyanathan A, Balaji M, 
Narendar R. Versatility of full thickness skin-subcutaneous fat grafts as interpositional material in the management of temporomandibular joint ankylosis. Int J Oral Maxillofac Surg 2011;40:506. https://doi.org/10.1016/j.ijom.2010.06.025

30. Malhotra VL, Singh V, Rao JD, Yadav S, Gupta P, Shyam R, et al. Lateral arthroplasty along with buccal fat pad inter-positioning in the management of Sawhney type III temporomandibular joint ankylosis. J Korean Assoc Oral Maxillofac Surg 2019;45:129-34. https://doi.org/10.5125/jkaoms.2019.45.3.129

31. Shakeel M, Imran M, Ahad B, Shafi M, Khan A. Surgical treatment of temporomandibular joint ankylosis: skims experience of 105 cases. Int J Med Res Health Sci 2016;5:77-82.

32. Sharma H, Chowdhury S, Navaneetham A, Upadhyay S, Alam S. Costochondral graft as interpositional material for TMJ ankylosis in children: a clinical study. J Maxillofac Oral Surg 2015;14:56572. https://doi.org/10.1007/s12663-014-0686-9

33. Qudah MA, Qudeimat MA, Al-Maaita J. Treatment of TMJ ankylosis in Jordanian children - a comparison of two surgical techniques. J Craniomaxillofac Surg 2005;33:30-6. https://doi.org/10.1016/ j.jcms.2004.07.005

34. Manganello-Souza LC, Mariani PB. Temporomandibular joint ankylosis: report of 14 cases. Int J Oral Maxillofac Surg 2003;32:249. https://doi.org/10.1054/ijom.2002.0308

35. Balaji SM. Modified temporalis anchorage in craniomandibular reankylosis. Int J Oral Maxillofac Surg 2003;32:480-5.

36. Loveless TP, Bjornland T, Dodson TB, Keith DA. Efficacy of temporomandibular joint ankylosis surgical treatment. J Oral Maxillofac Surg 2010;68:1276-82. https://doi.org/10.1016/ j.joms.2009.10.014

37. Tang W, Long J, Feng F, Guo L, Gao C, Tian W. Condyle replacement after tumor resection: comparison of individual prefabricated titanium implants and costochondral grafts. Oral Surg Oral Med Oral Pathol Oral Radiol Endod 2009;108:147-52. https://doi. org/10.1016/j.tripleo.2009.01.028

38. Chen S, He Y, An JG, Zhang Y. Recurrence-related factors of temporomandibular joint ankylosis: a 10-year experience. J Oral Maxillofac Surg 2019;77:2512-21. https://doi.org/10.1016/ j.joms.2019.06.172

39. Sahoo NK, Tomar K, Kumar A, Roy ID. Selecting reconstruction option for TMJ ankylosis: a surgeon's dilemma. J Craniofac Surg 2012;23:1796-801. https://doi.org/10.1097/ SCS.0b013e318270fab5

40. Wolford LM, Morales-Ryan CA, Morales PG, Cassano DS. Autologous fat grafts placed around temporomandibular joint total joint prostheses to prevent heterotopic bone formation. Proc (Bayl Univ Med Cent) 2008;21:248-54. https://doi.org/10.1080/08998280.200 8.11928404

41. Wolford LM, Mercuri LG, Schneiderman ED, Movahed R, Allen W. Twenty-year follow-up study on a patient-fitted temporomandibular joint prosthesis: the Techmedica/TMJ Concepts device. J Oral Maxillofac Surg 2015;73:952-60. https://doi.org/10.1016/ j.joms.2014.10.032

42. Mercuri LG. Patient-fitted ("custom") alloplastic temporomandibular joint replacement technique. Atlas Oral Maxillofac Surg Clin North Am 2011;19:233-42. https://doi.org/10.1016/ j.cxom.2011.05.001

43. Mercuri LG. Alloplastic temporomandibular joint replacement: rationale for the use of custom devices. Int J Oral Maxillofac Surg 2012;41:1033-40. https://doi.org/10.1016/j.ijom.2012.05.032

44. Wolford LM, Karras SC. Autologous fat transplantation around temporomandibular joint total joint prostheses: preliminary treatment outcomes. J Oral Maxillofac Surg 1997;55:245-51; discussion 251-2. https://doi.org/10.1016/s0278-2391(97)90535-8

45. Wolford L, Movahed R, Teschke M, Fimmers R, Havard D, Schneiderman E. Temporomandibular joint ankylosis can be successfully treated with TMJ concepts patient-fitted total joint prosthesis and autogenous fat grafts. J Oral Maxillofac Surg
2016;74:1215-27. https://doi.org/10.1016/j.joms.2016.01.017

46. Mercuri LG, Ali FA, Woolson R. Outcomes of total alloplastic replacement with periarticular autogenous fat grafting for management of reankylosis of the temporomandibular joint. J Oral Maxillofac Surg 2008;66:1794-803. https://doi.org/10.1016/ j.joms.2008.04.004

47. ShanYong Z, Liu H, Yang C, Zhang X, Abdelrehem A, Zheng $\mathrm{J}$, et al. Modified surgical techniques for total alloplastic temporomandibular joint replacement: one institution's experience. J Craniomaxillofac Surg 2015;43:934-9. https://doi.org/10.1016/ j.jcms.2015.03.028

48. Selbong U, Rashidi R, Sidebottom A. Management of recurrent heterotopic ossification around total alloplastic temporomandibular joint replacement. Int J Oral Maxillofac Surg 2016;45:1234-6. https://doi.org/10.1016/j.ijom.2016.02.017

49. Roychoudhury A, Yadav R, Bhutia O, Aggrawal B, Soni B, Gowswami D, et al. Is total joint replacement along with fat grafts a new protocol for adult temporomandibular joint ankylosis treatment? Int J Oral Maxillofac Surg 2017;46:236. https://doi.org/10.1016/ j.ijom.2017.02.797

50. Braimah R, Taiwo A, Ibikunle A, Oladejo T, Adeyemi M, Adejobi $\mathrm{F}$, et al. Clinical experience in managing temporomandibular joint ankylosis: five-year appraisal in a Nigerian subpopulation. J Korean Assoc Oral Maxillofac Surg 2018;44:112-9. https://doi. org/10.5125/jkaoms.2018.44.3.112

51. Park MW, Eo MY, Seo BY, Nguyen TTH, Kim SM. Gap arthroplasty with active mouth opening exercises using an interocclusal splint in temporomandibular joint ankylosis patients. Maxillofac Plast Reconstr Surg 2019;41:18. https://doi.org/10.1186/s40902019-0200-x

52. Lin CL, Kuo YC, Lo LJ. Design, manufacture and clinical evaluation of a new TMJ exerciser. Biomed Eng 2005;17:135-40. https:// doi.org/10.4015/S1016237205000214

53. Shirani G, Mohammadi F, Arshad M, Shirazi M. Temporomandibular joint ankylosis: case-series of two different surgical procedures. Dent Hypotheses 2014;5:103-8. https://doi.org/10.4103/21558213.136754

54. Ma Y, Huang Y, Zhu S, Li Y. Simultaneous arthroplasty and distraction osteogenesis for the treatment of ankylosis of the temporomandibular joint and secondary mandibular deformities in children. Br J Oral Maxillofac Surg 2019;57:135-9. https://doi.org/10.1016/ j.bjoms.2018.11.016

55. Zhang W, Yang X, Zhang Y, Zhao T, Jia J, Chang S, et al. The sequential treatment of temporomandibular joint ankylosis with secondary deformities by distraction osteogenesis and arthroplasty or TMJ reconstruction. Int J Oral Maxillofac Surg 2018;47:1052-9. https://doi.org/10.1016/j.ijom.2018.01.022

56. Mehrotra D, Vishwakarma K, Chellapa AL, Mahajan N. Prearthroplasty simultaneous maxillomandibular distraction osteogenesis for the correction of post-ankylotic dentofacial deformities. Int J Oral Maxillofac Surg 2016;45:820-7. https://doi.org/10.1016/ j.ijom.2015.10.009

57. Anchlia S, Vyas SM, Dayatar RG, Domadia HL, Nagavadiya V. Guidelines for single-stage correction of TMJ ankylosis, facial asymmetry and OSA in adults. J Maxillofac Oral Surg 2019;18:419-27. https://doi.org/10.1007/s12663-018-1121-4

58. Sharma R, Manikandhan R, Sneha P, Parameswaran A, Kumar JN, Sailer HF. Neocondyle distraction osteogenesis in the management of temporomandibular joint ankylosis: report of five cases with review of literature. Indian J Dent Res 2017;28:269-74. https://doi. org/10.4103/ijdr.IJDR_292_13

59. Gabbay JS, Heller JB, Song YY, Wasson KL, Harrington H, Bradley JP. Temporomandibular joint bony ankylosis: comparison of treatment with transport distraction osteogenesis or the Matthews device arthroplasty. J Craniofac Surg 2006;17:516-22. https://doi. org/10.1097/00001665-200605000-00022

60. Boyd SB. Management of obstructive sleep apnea by maxillo- 
mandibular advancement. Oral Maxillofac Surg Clin North Am 2009;21:447-57. https://doi.org/10.1016/j.coms.2009.09.001

61. Vijaya Krishnan P, Raghunandhan S, Anand Kumar RS, Kameswaran $\mathrm{M}$. A rational approach to the management of obstructive sleep apnea syndrome. Indian J Otolaryngol Head Neck Surg 2014;66(Suppl 1):138-46. https://doi.org/10.1007/s12070-0110381-9

62. Zanaty O, El Metainy S, Abo Alia D, Medra A. Improvement in the airway after mandibular distraction osteogenesis surgery in children with temporomandibular joint ankylosis and mandibular hypoplasia. Paediatr Anaesth 2016;26:399-404. https://doi. org/10.1111/pan.12869

63. Bouchard C, Troulis MJ, Kaban L. Management of obstructive sleep apnea: role of distraction osteogenesis. Oral Maxillofac Surg Clin North Am 2009;21:459-75. https://doi.org/10.1016/ j.coms.2009.07.001

64. Sesenna E, Magri AS, Magnani C, Brevi BC, Anghinoni ML. Mandibular distraction in neonates: indications, technique, results. Ital J Pediatr 2012;38:7. https://doi.org/10.1186/1824-7288-38-7

65. Flores RL. Neonatal mandibular distraction osteogenesis. Semin Plast Surg 2014;28:199-206. https://doi.org/10.1055/s-00341390173

66. Ching JA, Daggett JD, Alvarez SA, Conley CL, Ruas EJ. A simple mandibular distraction protocol to avoid tracheostomy in patients with Pierre Robin sequence. Cleft Palate Craniofac J 2017;54:2105. https://doi.org/10.1597/14-211

67. Tahiri Y, Viezel-Mathieu A, Aldekhayel S, Lee J, Gilardino M. The effectiveness of mandibular distraction in improving airway obstruction in the pediatric population. Plast Reconstr Surg 2014;133:352e-9e. https://doi.org/10.1097/01. prs.0000438049.29258.a8

68. Genecov DG, Barceló CR, Steinberg D, Trone T, Sperry E. Clinical experience with the application of distraction osteogenesis for airway obstruction. J Craniofac Surg 2009;20 Suppl 2:1817-21. https://doi.org/10.1097/SCS.0b013e3181b6c1b0

69. Lam DJ, Tabangin ME, Shikary TA, Uribe-Rivera A, Meinzen-Derr $\mathrm{JK}$, de Alarcon A, et al. Outcomes of mandibular distraction osteogenesis in the treatment of severe micrognathia. JAMA Otolaryngol Head Neck Surg 2014;140:338-45. https://doi.org/10.1001/ jamaoto.2014.16

70. Gunaseelan R, Anantanarayanan P, Veerabahu M, Vikraman B. Simultaneous genial distraction and interposition arthroplasty for management of sleep apnoea associated with temporomandibular joint ankylosis. Int J Oral Maxillofac Surg 2007;36:845-8. https:// doi.org/10.1016/j.ijom.2007.05.004

71. Li KK, Powell NB, Riley RW, Guilleminault C. Distraction osteogenesis in adult obstructive sleep apnea surgery: a preliminary report. J Oral Maxillofac Surg 2002;60:6-10. https://doi.org/10.1053/ joms.2002.29049

72. Feiyun P, Wei L, Jun C, Xin X, Zhuojin S, Fengguo Y. Simultaneous correction of bilateral temporomandibular joint ankylosis with mandibular micrognathia using internal distraction osteogenesis and 3-dimensional craniomaxillofacial models. J Oral Maxillofac Surg 2010;68:571-7. https://doi.org/10.1016/j.joms.2009.07.022

73. Miloro M. Mandibular distraction osteogenesis for pediatric airway management. J Oral Maxillofac Surg 2010;68:1512-23. https://doi. org/10.1016/j.joms.2009.09.099

74. Jia W, He Y, Helal H, Wang Y, Li J. One-stage technique for treatment of ankylosis of the temporomandibular joint, secondary micrognathia, and a prominent mandibular angle. Br J Oral Maxillofac Surg 2019;57:701-3. https://doi.org/10.1016/ j.bjoms.2019.05.022

75. Srivastava D, Luthra P, Mishra S, Chandra L, Sharma S, Singh H. Technique of dual distraction for correction of unilateral temporomandibular joint ankylosis with facial asymmetry: a case series. J Oral Maxillofac Surg 2019;77:2555.e1-12. https://doi.org/10.1016/ j.joms.2019.07.017

76. Yadav R, Bhutia O, Shukla G, Roychoudhury A. Distraction osteogenesis for management of obstructive sleep apnoea in temporomandibular joint ankylosis patients before the release of joint. J Craniomaxillofac Surg 2014;42:588-94. https://doi.org/10.1016/ j.jcms.2013.07.031

77. Zhu S, Wang D, Yin Q, Hu J. Treatment guidelines for temporomandibular joint ankylosis with secondary dentofacial deformities in adults. J Craniomaxillofac Surg 2013;41:e117-27. https://doi. org/10.1016/j.jcms.2012.11.038

78. Gonçalves JR, Gomes LC, Vianna AP, Rodrigues DB, Gonçalves DA, Wolford LM. Airway space changes after maxillomandibular counterclockwise rotation and mandibular advancement with TMJ Concepts ${ }^{\circledR}$ total joint prostheses: three-dimensional assessment. Int J Oral Maxillofac Surg 2013;42:1014-22. https://doi.org/10.1016/ j.ijom.2013.04.009

79. Coleta KE, Wolford LM, Gonçalves JR, Pinto Ados S, Cassano DS, Gonçalves DA. Maxillo-mandibular counter-clockwise rotation and mandibular advancement with TMJ Concepts total joint prostheses: part II--airway changes and stability. Int J Oral Maxillofac Surg 2009;38:228-35. https://doi.org/10.1016/j.ijom.2008.11.021

How to cite this article: Upadya VH, Bhat HK, Rao BHS, Reddy SG. Classification and surgical management of temporomandibular joint ankylosis: a review. J Korean Assoc Oral Maxillofac Surg 2021;47:239-248. https://doi.org/10.5125/jkaoms.2021.47.4.239 